\title{
An Examination of the Position of the Law on Alternative Care for Children in Edo State
}

\author{
Stella O. Idehen ${ }^{1}$, Maryam Cam ${ }^{2}$ \\ ${ }^{1}$ Faculty of Law, Benson Idahosa University, Benin, Nigeria \\ ${ }^{2}$ SOS Children's Villages, Benin, Nigeria \\ Email: sidehen@biu.edu.ng,maryam.Cam@sosnigeria.org
}

How to cite this paper: Idehen, S. O., \& Cam, M. (2021). An Examination of the Position of the Law on Alternative Care for Children in Edo State. Beijing Law Review, 12, 392-408.

https://doi.org/10.4236/blr.2021.122022

Received: February 5, 2021

Accepted: April 23, 2021

Published: April 26, 2021

Copyright ( 2021 by author(s) and Scientific Research Publishing Inc. This work is licensed under the Creative Commons Attribution International License (CC BY 4.0).

http://creativecommons.org/licenses/by/4.0/ cc (i) Open Access

\begin{abstract}
An examination was carried out on the Child Rights Law 2007 and the Children Protection Policy 2015 of Edo State and other relevant legislations with a view of finding the position of the law on alternative care in Edo State. The work discovered that alternative care provided in both legislations mainly focused on institutional formal care or altogether did not provide for informal alternative care. There is the need for informal care to be considered as a result of the fact that most of the incidences of child abuse stem from this area. The United Nation Guidelines was also examined and it was discovered that a lot of gaps exist in our legislations. Research also extended to review of relevant literature on studies on alternative child care system as well as internet sources to enrich this work. The paper makes recommendations for a reform, increase in funding and other relevant concerns that will enhance a more effective implementation of alternative care in Edo State.
\end{abstract}

\section{Keywords}

Child, Rights, Law, Alternative Care, Reform

\section{Introduction}

The family is the basic and primary group in any society and also the foundation upon which society revolves. The family is one that is made up of parents or elderly ones and children and ensures that everyone is cared for and loved thus the family is seen as the best place for the growth, well-being and protection of children. This is an important factor as where children do not receive love and care; it impacts negatively on them and destroys their hopes and aspirations for a better future. The SOS Villages international have discovered in their work with children that the most vulnerable children are those without parents or who are at 
risk of losing parental care (SOS Villages, 2018). They believe that it is in the best interest of children to remain with their family of origin as long as the family is providing adequate care and where it is not possible, the child is to be put in a family that is like his/her original home.

Nnama-okechukwu et al. (Nnama-Okechukwu and Okoye, 2019) in their article found that the need for alternative child care in Nigeria is urgently needed as the increasing reports and studies have shown the negative impact of institutional care on child development. They state that the children living in institutions often lack individual care and are cut off from their communities.

As a result of the need to protect the children and their rights, the United Nations Convention on the Rights of the Child was signed in 1989 and many countries including Nigeria have ratified and domesticated the Child Rights Act in 2003. Edo State is also one of the states in Nigeria to enact the Child Rights Law in 2007. The intent of the Child Rights Law is to protect the rights of the Edo State child and other related matters.

In 2015, the Edo State Child Protection Policy was enacted with the intent of protecting children from abuse, discrimination, exploitation, violation and organizational negligence (Ministry of Women Affairs, 2015). In 2018, another policy titled End Violence against Children was made with the aim of protecting children against violent acts. Cases of abuse of children has been rife particularly those placed in informal care. The Guardian newspaper reports of $26^{\text {th }}$ July, 2018 reports that incidences of child abuse and sexual abuse against children are on the increase. The paper carried a report of the arrest of a 70-year-old man, Francis Ezomo and his two sons, Nosa Ezomo, 26 years and Festus Ezomo, 29 years old for allegedly defiling a nine-year-old girl who is a relative of Francis Ezomo's wife (The Guardian newspaper, 2018). Another incident was reported by the Independent Television/Radio on the $5^{\text {th }}$ October, 2020 where the Edo State Government ordered the arrest of a woman alleged to have subjected an infant to child labour and abuse. The State Commissioner of Social Development and Gender Issues issued the order while reacting to a complaint by one Gift Edekhan of alleged molestation by her aunt (ITV, 2020). Those in formal care especially the girl child are turned into baby making factories where their babies are sold with the connivance of the unscrupulous owners of these orphanages (Edo State Government, 2020).

The Department of Child Development in the Ministry of Social Development and Gender Issues is the regulatory body that monitors the effective implementation of these legislations.

Though the Federal government of Nigeria and Edo State have taken steps to ensure that the child is protected and cared for through these and other related legislations, there are still gaps that urgently needs to be addressed for a more effective means of implementing these laws and policy concerning children.

As a result of the above issue, this work shall examine extant laws that are put in place for children to find out the position of the laws in respect of alternative 
care for children with a special focus on children who are taken away by relatives or persons in trust to cater for such children.

\section{Alternative Care Defined}

Alternative care is defined as any arrangement, formal or informal, temporal or permanent for a child who is living away from his or her parents (Federal Government of Nigeria, 2020). Children are meant to stay with their families however, difficulties arise for families who are unable to provide the basic necessities which children are to enjoy while growing up. Parents in this unfortunate position are willing to give their children to relatives or trusted persons who they believe will provide alternative care in a conducive environment that will give them better opportunities in life. However, on a daily basis, ugly incidents are reported of vulnerable and hapless children in alternative care, who are constantly brutalized by their so called caregivers, some of whom are relatives who promise their parents a better life for the children only to end up as sex slaves, house helps, hawkers etc. These unscrupulous persons subject the children to various types of abuse (physical, emotional, sexual, verbal abuse etc.). It has been reported that six out of every ten children experience some form of violence (UNICEF, 2020).

It thus becomes pertinent at this junction to examine some of our laws relating to children with a view to find out if adequate legal provisions have been made in respect of alternative care for children in Edo State and proffer recommendations that would address these gaps.

\section{Examination of Laws Relating to Children Alternative Care}

\subsection{The Edo State Child Rights Law 2007}

The Edo State Child Rights Law 2007 (ESCRL) was enacted to provide and protect the rights of Edo children and other related matters and its provisions are similar to that of the Child Rights Act 2003.

Section 1 of the ESCRL states that in all actions relating to a child whether undertaken by individual, public or private body, institutions or service, court of Law or administrative or legislative authority, the best interest of every child is of paramount consideration. It is interesting to note that the best interest of a child is not clearly defined as parameters are not given as to what best interest means. Thus it is left to individuals to determine what the term is and this can cause a lot of confusion. It is suggested that a concise definition of the term be provided for in the ESCRL.

Provision is made for a child to be given such protection and care as is necessary for the well-being of the child taking into account the rights and duties of the child's parents, legal guardians or other individuals, institutions, services, agencies, organisations or bodies legally responsible for the child (ESCRL, 2007).

It is important to note that the interest of the Edo child is of utmost importance and as such the Government of Edo State is to ensure that the interest and 
well -being of every child is taken care of by enacting laws for protection of the child, which is provided for though the question now is whether the best interest of the child has been taken into consideration.

Part II, Sections 3 - 15 clearly states the rights of a child and these rights include the application of Chapter IV of the 1999 Constitution of Nigeria as amended (Constitution FRN, 1999) are recognized and applicable as if those provisions are expressly stated in the Child Rights Law. Other rights are also stated, which relate to the fundamental rights, right to survival and development, (ESCRL, 2007, Section 4), right to name, (ESCRL, 2007, Section 5) right to private and family life (ESCRL, 2007, Section 8), etc.

To further emphasize the importance of the rights of a child, provision in the Law is made for a right to dignity of the child and that no child shall be subjected to the following;

1) Physical, mental or emotional injury, abuse, neglect or maltreatment including sexual abuse.

2) torture, inhuman or degrading treatment or punishment.

3) attacks upon his honor or reputation.

4) held in slavery or servitude while in the care of a parent, legal guardian or school authority or any other person or authority having the care of the child.

It is important to note that despite the above provisions, children still suffer the above forms of abuses and maltreatment which makes them scarred for life.

Section 14 is worthy of mention and it states that every child has a right to parental care and protection and accordingly no child shall be separated from his parents against the wish of the child except for the following reasons;

1) for the purpose of his education and welfare

2) in the exercise of a judicial determination in accordance with the provisions of the law in the best interest of the child.

It is to be noted that the above section has been abused by both parents and so called caregivers in removing a child from his/her family with the promise of attending school which is most often not the case. Most often the wishes of the child are never sought and this is done informally without government playing a major role. This probably accounts for the high rate of domestic violence on children.

Part IV provides for the protection of children and states that the State Government or an appropriate authority can apply to court for a child assessment order if it appears or has reasonable cause to suspect that the child is suffering or likely to suffer significant harm (ESCRL 2007: p. 38).

Certain persons like the child development officer, police officer or any other person authorized by the Commissioner are empowered to apply to court on behalf of the child if there is reason to believe that the child is an orphan or is deserted by his relatives, neglected or ill-treated or battered by the person having the care and custody of the child, is found wandering or has no home or settled place of abode, is on the street or other public place or has no visible means of subsistence, is found begging, accompanies any person when that person is beg- 
ging or receiving alms and other unwholesome conduct to cause the courts to make the parents or guardian of the child to enter into a recognizance to exercise proper care and guardianship over the child, make a corrective order, commit the child to the care of any one relative or not, who is willing to take care of the child or send the child to an approved institution (ESCRL, 2007: 47(1)(2)(3)). This provision has not been strictly complied with, as a lot of children still roam the streets.

It is noted that section 47(3) takes cognizance of alternative care and is commendable but does not provide further details to ensure that a register is open to collect the data of both the child and the person willing to take care of the child as well as make provisions for follow up by welfare officers to ensure that the child is adequately taken care of.

Powers are given to the court to make orders as follows where a parent/guardian is unable to exercise control to place a child for a specified period not exceeding three years under a supervisory child development officer or any appointed person by the court and make a care order or supervision order in respect of a child based on application of a local government, appropriate authority or any other authorized person (ESCRL, 2007, Sections 50 \& 51).

For an effective implementation of the law, provision is made for follow up and while a supervision order is in force, supervisors are expected to advise, assist, befriend the child, take such steps as are reasonable necessary to give effect to the order, etc. (ESCRL, 2007: Section 54). It is noted that above provision is laudable as a follow up mechanism is put in place to ensure the protection of the wellbeing of the child.

Part VIII is concerned with possession and custody of children and provides for where the process for acquisition of parental responsibility is spelt out for instance section 65(a) states that the fact that a person has or does not have parental responsibilities for a child shall not affect any obligation which he may have in relation to the child which includes a statutory duty to maintain the child etc. It further states that a person shall do what is reasonable for the purpose of safeguarding or promoting the welfare of the child. It is submitted that if this provision is effectively implemented, this provision will ensure that every child in alternative care will be well taken care of.

Section 76(1) states that the Commissioner may by order prohibit the giving or acquiring of the custody, possession, control or guardianship of a child or removal of a child from any part of a local Government of the state. The Child Rights Law also state that no person shall give or acquire the custody, possession, control of or remove a child from any part of the local government specified in the order when an order is made by the Commissioner. This however is difficult to implement as there are no adequate data that is available for children to allow for adequate monitoring (ESCRL, 2007: Section 76(2), 77(1-3)).

The Law takes care of the prohibition of acquiring custody, possession, control or guardianship of a child whether or not for pecuniary or other benefit in 
circumstances where it can reasonably be inferred that the child has been hired, sold or battered or by reason of the hiring, giving or acquiring, the child may reasonably be inferred to be in danger.

The Law also provides for other forms of alternative care that is regarded as formal care. For instance, Section 79 provides for guardianship of a child and the process of appointment of guardians, fostering, adoption, child minding/daycare, community homes, voluntary homes and registered homes (ESCRL 2007: Sections 80-145).

The highlight of the provisions on formal alternative care is the provision for the creation of registers and visitations by child development officers to monitor the various institutions. This is quite laudable as it would ensure that the interest and wellbeing of a child is not compromised. Where breaches occur, the creation of the family court at two levels namely the High court and magistrate court with both courts having general jurisdiction in civil and criminal proceedings is available to hear the existence or extent of a legal right, power, duty, liability, privilege, interest, obligation or claim in respect of a child in civil issues and criminal proceedings relating to penalty, forfeiture, punishment or other liability in respect of an offence committed by a child (ESCRL 2007: Part XIII).

A summary of an in-depth study of the Child Rights Law 2007 show that the it is quite comprehensive and covers a wide range of issues that takes into cognizance the best interest of the child and this has been highlighted in the above provisions. It is however noted that $t$ though formal alternative care has been provided by various means like fostering, volunteering homes and organisations, etc. There appears to be an area of alternative care that has not been adequately considered and this is in respect of informal care where individuals take children from parents without the involvement of government thereby such children are not monitored as there is no mechanism put in place where such persons can obtain approval and proper documentation taken so as to be able to monitor the wellbeing of such child.

It is submitted that the Child Rights Law did not provide for this and it should be looked into by the State Government. Another observation is how effective the Edo State Government has been in ensuring a strict compliance of the Child Rights Law is yet to be seen as a lot of children are seen on the streets begging, hawking and being used as house helps. It is also noted that the Child Rights Law was enacted in 2007 while the United Nations Guidelines for Alternative care was created in 2010. This may be why the Child Rights Law does not comprehensively cater for other forms of family-based or family-like care placements. This therefore creates a need for amendment of the ESCLR to provide fill this gap.

\subsection{Edo State Child Protection Policy 2015}

The Policy is divided into 14 sections and states that the protection of children rights is essential for safeguarding children and adolescents from all forms of abuse, neglect, violation and exploitation (Child Protection Policy, 2015: Section 
1). The policy notes that the Child Rights Law is focused extensively on the protection of the rights and interests of children and has adopted this position also.

The Policy further recognizes the growing trend of cases of abuse and violations of the rights of the child and observes that from records survey conducted in 2014, there has been a limited implementation of the existing legal framework on child protection in Edo State.

The Policy acknowledges that some individuals abuse children as part of their punitive measures to correct behavior and engage in all other manner of unwholesome abuses and when this is discovered, families of the victims are usually reluctant to cooperate with the prosecution of such cases as a result of fear of stigma and discrimination. The Policy further states that attempts to integrate protection issues into activities of institutions and existing structures that utilize existing policies have not given the needed response to strengthen the child protection system (Child Protection Policy, 2015). This and many other reasons form the major drive for the development of this policy which will speak in the best interest of the child.

In carrying out its policy statement, the Policy states that Edo State is committed to formulating, coordinating, implementing, monitoring and evaluating programs that prioritize the rights of the child as declared in the United Nations Convention on the Rights of the Child 1989, Child Rights Act 2003 and the Edo State Child Rights Law, 2007 (Child Protection Policy, 2015: Section 2). The Policy recognises that in every action concerning a child, the best interest of a child shall be a primary consideration. It is observed that the Policy has also failed to define the term "best interest" and this should be addressed to give it the true definition it deserves. Section 2(4) states that all reasonable steps shall be taken to protect children from harm and discrimination as well as from degrading treatment and to respect their rights, wishes and feelings.

Section 2(5) state that all suspicions and allegations of poor practice or abuse will be taken seriously and responded to swiftly and appropriately ensuring that all children have a legal identity while section $2(7)$ provides that a working partnership with parents/guardians/caregivers and children is essential for the protection of children and upholding their rights to participate in issues that concern them. It is doubtful if this provision has been fully implemented as a lot of children are not properly monitored and are on the streets with no homes particularly as the number of domestic abuse of child has continued unabated and this calls into question the efficacy of the Policy.

The purpose of the Policy which is summarized as follows; to address protection issues affecting children, to commit organisations, institutions and establishments in the state to protect children from all forms of abuse (sexual abuse, female genital mutilation, domestic violence, etc.), ensure that all stakeholders are clear about their roles and responsibilities concerning children, direct the ways in which organisations in the State conduct their activities and their behavior towards children, ensure consistency on how to respond to issues of child 
protection and to provide a framework for the effective coordination of the child protection in the state (Child Protection Policy, 2015: Section 3). It however does not appear that there has been proper coordination of the Policy towards the protection of the children in alternative care as the Ministry concedes to its inability to perform its functions as a result of factors like paucity of funds, lack of vehicles to undertake monitoring, etc. (Patience, 2020).

Provision is made for interventions where reports are made concerning abuse or exploitation of any child by any person including colleagues, family members or law enforcement officers as well as the recruitment of personnel that would have contact with children and procedures for selection of such persons (Child Protection Policy, 2015: Section 5). The Policy further provides for ensuring that the infrastructure and physical protection of the environment is safe for children and states minimal standards for such facilities.

Information on the appropriate agencies for responding and reporting abuse cases such as domestic violence, rape, child trafficking etc. (Child Protection Policy, 2015: Section 7) and also refer to commitment to children which talks about social responsibility, accountability, behavior, equality and practices which discourage corporal punishment or use of offensive or abusive language on children (Children Protection Policy, 2015: Section 8). It is noteworthy to state that the Policy is applicable to Edo State and all local government councils, institutions and organisations, all child friendly structures, orphanages and child-related institutions as well as all employers and also states the Policy implementation which would ensure a coordinated policy by enjoying support of the three arms of government as well as creating staff awareness of child protection obligations (Children Protection Policy, 2015: Section 9 \& 10). Section 11 is all about monitoring and evaluation by the Edo State Child Rights Law Implementation Committee to ensure compliance with guidelines.

A summary of the Policy show that it is a detailed statement which further buttresses the aspirations of the Child Rights Law 2007 on the need to protect the best interest of the child. However, it is observed that despite the elaborate provisions, no adequate provision has been made in respect of informal care in the form of protecting a child when a relative or individual takes a child from a poor family with a promise to take care of the child which often is not the case. It is also observed that the Policy acknowledges that incidences of all types and manner of abuse have been inflicted on children and until it is reported, such a child suffers in silence. One would have thought that provision would been made in respect of this particular issue regarding informal care that is a huge challenge that needs to be destroyed from its root. Though provision is made for monitoring and evaluation of the Policy, it however remains to be seen how this Policy has impacted on children as on a daily basis, children are abused in Edo State.

It is therefore important to identify how these abuses can be prevented from the very beginning when the family gives out the child to a relative or an indi- 
vidual, there ought to be a means of monitoring the child and this can be effectively implemented by a unit that can be created in the Ministry of Social Development and Gender Issues, where such movement of a child to an alternative care can be properly monitored to ensure that abuse of whatever kind is eliminated.

\subsection{Constitution of the Federal Republic of Nigeria, 1999 as Amended}

Section 17 provides for social objectives under Chapter II of the Fundamental Objectives and Directive Principles of State Policy. Of particular importance is section 17(f) which provides that children; young persons and the aged are protected against any exploitation whatsoever, and against moral and material neglect. Section $7(\mathrm{~h})$ also states that the evolution and promotion of family life is encouraged.

Chapter IV further provides for fundamental rights which are applicable to all children. The provisions of the Constitution presume that the child is expected to grow up in a conducive family environment and be protected from all kinds of harm (Edo State Child Rights Law, 2007).

\subsection{Criminal Code Law, Edo State}

Chapter 21 provides for offences against Morality. This is where provisions for indecent treatment of boys and girls are made (Edo State, 1976: Sections 214$233 \mathrm{~A}, \mathrm{CC})$. Section 295 makes provision for the correction of a child however it states that correction should not be unreasonable. (Section 295(4) (5)(6)CC) Section 301 makes provision for necessaries of life to be given to children by parents. Provision against child stealing and desertion of children are stated in sections $371 \& 372$ and is punishable by imprisonment for 14 years and one year respectively. The Criminal Code Law does not however make provision for alternative care.

\subsection{Administration of Criminal Justice Law 2016}

Section 371 provides for the summary trial of a child by a Magistrate and that the court shall have regard to the provisions of the Child Rights Law. There are no provisions for alternative care for children.

\subsection{Edo State Family Court (Civil Procedure) Rules 2017}

The family court was created in 2017 to enforce the rights of the child and is a creation of the Child Rights Law. Its overriding objective is to give protection and care for the wellbeing of the child, taking into consideration the rights and duties of the child's parents, legal guardians, individuals, institutions, services, agencies having regard to the best interest and welfare of any child.

An examination of the various laws has been carried out and it can be seen that only the Child Rights Law and the Child Protection Policy of Edo State pro- 
vides for formal alternative care which is not recognized in the other legislation discussed above. It is therefore needful for this issue to be addressed in the laws relating to children so as to help the child grow up in homes that are almost like their original family homes or after a while be reunited with their families.

\section{Position of United Nations Guidelines for the Alternative Care of Children 2009}

As a result of the fact that many children remain in homes who are unable to offer them adequate care because they are too poor and lack adequate support. The United Nations Guidelines (Guidelines) in an attempt to enhance the implementation of the Convention on the rights of the Child offer guidance on actualising rights for children and encourage States to take the Guidelines into account when enacting legislations and to bring them to the attention of the relevant, legislative and judiciary bodies of government, human rights defenders and lawyers, the media and the public with respect to the protection and well -being of children who are deprived of parental care or who are at risk of being deprived, to support efforts to keep children in, or return them to, the care of their family or to find another appropriate and permanent solution which includes adoption and kafala of Islamic law, to ensure that, while permanent solutions are being sought, or in cases where they are not possible or are not in the best interests of the child, the most suitable forms of alternative care are identified and provided, under conditions that promote the child's full and harmonious development, to assist and encourage governments to better implement their responsibilities and obligations and to guide policies, decisions and activities of all concerned with the social protection and child welfare.

The guidelines also make provision for general principles and perspectives which provides inter alia for the following: child and the family-where efforts should be primarily directed to enabling the child remain in or return to the care of his/her parents or when appropriate, other close family members and to ensure that families have access to forms of support in caregiving role. Provision is also made for alternative care. Section 11 provides for all decisions with respect to alternative care, to take full account of the desirability, in principle of maintaining the child as close as possible to his/her habitual place of residence, in order to facilitate contact and potential reintegration with his/her family and to minimize disruption of his/her educational, cultural and social life.

\subsection{Analysis of Provisions on Alternative Care for Children}

The guidelines deal particularly with children living under alternative care and makes provisions for children under formal and informal care by ensuring that due regard for the importance of ensuring a stable home and of meeting their basic need for a safe environment is top priority. Unlike the guidelines, the Child Rights Law of Edo State caters mainly for those in formal institutionalized alternative care and no adequate provisions are made for those in informal care (Save 
the Children Resource Center, 2012: Section 12).

In ensuring that children are taken care of, it advocates for treatment of children with dignity and respect at all times who must benefit from effective protection from abuse, neglect and all forms of exploitation from care providers, peers or third parties in whatever setting they find themselves (Save the Children Resource Center, 2012: Section 13).

The guidelines further stresses that the removal of a child from the care of the family should be a last resort and should whenever possible be seen as temporary and for the shortest possible duration. Removal decisions should be reviewed regularly so that the child's return to his parents can be done as soon as the original cause for removal is resolved or have disappeared and should be in the best interest of the child (Save the Children Resource Center, 2012: Section 14). Section 15 states that financial and material poverty or conditions directly and uniquely imputable to such poverty should never be the only justification for the removal of a child from parental care, for receiving a child into alternative care or for preventing his /her reintegration but should be seen as a signal for the need to provide appropriate support to the family. In Edo State, issues like poverty has been a major cause for children to be given out informally or abandoned and it is yet to addressed by the government.

Section 18 recognizes that in most countries, majority of children without parental care are looked after informally by relatives or others and as such, States are enjoined to seek to devise appropriate means, consistent with the guidelines, to ensure their welfare and protection in such informal care arrangements. This is not adequately provided for in the Child Rights Law. There is therefore need to amend the Child Rights Law to address this area.

The guidelines also provide for measures to promote its application by encouraging states to allocate human and financial resources to ensure optimal and progressive implementation of the guidelines throughout their respective territories in a timely manner and facilitate active cooperation among all relevant authorities and to seek also international cooperation (Save the Children Resource Center, 2012: Sections 24 \& 25). It does not appear if the funds allocated to the Edo State Ministry are adequate to take care of the timely and progressive implementation of the guidelines. At a stakeholder's conference, the Ministry complained of lack of funds to effectively carry out their regulatory and monitoring responsibilities (Patience, 2020). There is need for collaboration in the area of international cooperation. It is suggested that an agency be set up to drive this goal particularly in respect of drawing up plans to generate funds to achieve the goals of the guidelines.

\subsection{Application of the United Nations Guidelines}

The scope of the guidelines is stated in sections 27 to 30 and includes the application of the guidelines to all persons below 18 years old in alternative formal care and also apply to informal settings having due regard for the important role 
played by extended family and community. It is observed that guidelines for formal care are well detailed in the Child Rights Law however the informal care should also be adequately addressed to allow for proper monitoring of the child.

Part iv provide for preventing the need for alternative care and is divided into part A \& B Part A; Sections 32 to 48 covers this. This is done by encouraging States to pursue policies that ensure support for families in meeting their responsibilities towards the child as well as promoting the right of the child to have a relationship with both parents and addresses issues of child abandonment, relinquishment and separation of child etc. (Save the Children Resource Center, 2012: Section 32). This is because research shows that family and community based forms of care are more likely to meet the needs of children than residential care in institutions so that children can be placed with relatives in foster care or other family-like settings or in residential institutions (The Faith to Action Initiative, 2014).

Part B provides for the promotion of family reintegration and for follow-up and support measures (Save the Children Resource Center, 2012: Sections 48-52). Determination of the most appropriate form of care is another provision in the guidelines that takes cognizance of issues which includes inter alia, decisionmaking on alternative care in the best interests of the child should take place through a judicial, administrative or other adequate and recognized procedure (Save the Children Resource Center, 2012: Sections 57-68). Part vii makes provision for alternative care which is about policies where responsibility is placed on States to ensure development and implementation of coordinated policies with respect to formal and informal care for all children without parental care (Save the Children Resource Center, 2012: Section 69).

Section 70 provides for states to cooperate with civil society and adopt policies which favour information sharing and networking between agencies and individuals in order to ensure effective care, aftercare and protection for children without parental care. It is noted that the Child Rights Law and the Child Protection Policy, Edo State have not fully implemented these provisions.

Sections 76-79 provides for informal care. Section 79 is worthy of mention where states are to devise special and appropriate measures designed to protect children in informal care from abuse, neglect, child labour and all other forms of exploitation, with particular attention to informal care provided by non-relatives or by relatives previously unknown to the children or living far from the children's habitual place of residence. It is noted that this is where children who are given out to relatives or strangers in Nigeria are not monitored to prevent children in Edo state from being brutalized and perhaps accounts for the increase in the dehumanizing treatment meted out to children under this type of care. There is therefore the need to make provisions for this type of informal care.

The guidelines make provisions for general conditions applying to all forms of formal alternative care arrangements and is covered by Sections 80-100. Sections 101-103 provides for legal responsibility for the child where parents are absent 
or incapable of making decisions on a daily basis, responsibility is placed on a designated individual or competent entity by a competent administrative or judicial authority to make decisions for the child. Sections 105-117 makes provisions for agencies and facilities responsible for formal cares and states that all of these bodies be registered before they can commence operation.

Provision is made for foster care, residential care, inspection and monitoring and support for aftercare (Save the Children Resource Center, 2012: Sections 118136). These provisions are also replicated in the Child Rights Law and the Edo State Child Protection policy. Part ix makes provisions for care in emergency situations where the guidelines should continue to apply in emergency situations as well as encouraging organisations and authorities in making efforts in preventing separation of children from parents or primary caregivers (Save the Children Resource Center, 2012: Sections 155-156).

Care arrangements have been provided for in Sections 157 to 161 where communities should be assisted in playing an active role in monitoring and responding to care and protection issues facing children and other related issues and Sections 162 to 167 makes provision for tracing and family reintegration where children are identified and registered and reintegrated with their parents and documents are kept confidential. This does not appear to be the case in Edo State as there are no clear roles in the law where communities can participate neither is there data on how families can be located for the purposes of reintegration.

In concluding, the main purpose of the guidelines is to get nations to consider alternative care among the many range of options in taking care of the needs of children by ensuring that children are given a voice so that their wishes can be carried out. This however is almost nonexistent despite the presence of the Child Rights Law in Edo State.

\subsection{An Examination of the Position of Alternative Child Care in Edo State}

An in-depth examination of the Child Rights Law, Edo state and the Child Protection Policy have been examined and it is observed that both documents have provisions that have incorporated the UN Guidelines for the Alternative Care of Children as well as the Convention on the Rights of the Child 1989. The Child Rights Law in its sections focuses extensively on the protection of the rights and interests of the child while the Policy ensures that there is a working document on the rights of children that can serve as a guide for intervention on issues that concern children and to address gaps in the child protection system. How these documents have translated to an effective implementation is one that is difficult to evaluate. This is because provisions for informal care are not attended to neither have efforts been made towards an effective implementation of the Guidelines. However, a good development that has come out of this however is the creation of Family Court in 2017 which the Child Rights Law makes provisions 
for. The Edo State Family Court (Civil Procedure) Rules 2017 have been enacted to regulate proceedings relating to the rights, advancement and welfare of the child under the Edo State Child Rights Law 2007. This shows that Edo State has to a large extent made efforts to align itself with the provision of alternative care for Edo State, though more work needs to be done.

The necessity principle of the UN Guidelines on Alternative Care for Children involves prevention of situations and conditions that can lead to alternative care is not clearly defined in the Child Rights law neither is the suitability principle provided for. This as a result of the fact that the Child Rights Law was enacted in 2007 while the Guidelines was drawn in 2009 thus creating the need to amend the Child Rights Law to incorporate these principles that would aid in providing better care and protection for children to be cared for in an environment that is most suitable for them. These principles allow children have a voice in choosing where to live/stay. The UN guidelines on Alternative care tries as much as possible to discourage placement of children in alternative care homes and when this is done, it is expected that all measures be taken within a short period to ensure reintegration with the family and follow ups are also encouraged to build up the family. In addition, where this is not possible, to ensure that the most suitable forms of alternative are identified and provided that will help promote the child's full and harmonious development. This have not been provided in the Child Rights Law of Edo State and the Child Protection Policy as provisions for institutional formal care is provided in respect of making provisions for fostering, adoption, guardianship, community homes, children's home etc.

Despite the above provisions, it is observed that the Child Rights Law and the Policy do not have clear provisions for reintegration of children who are in alternative care. To strengthen the family and help in capacity building, Government can collaborate with NGOs, voluntary bodies, corporate and private organization to identify families who can be supported which will prevent children from being separated from their homes. This situation can be controlled with the proper monitoring by government in ensuring that these children are placed in homes that is conducive for their growth and development for instance, it becomes necessary for budget allocation to be created to help families and also young girls who are pregnant to give birth in an appropriate hospital where adequate arrangements are made for adoption and all relevant papers signed by government and parties concerned so as to monitor the progress of the child by social workers. Government must also employ enough persons who will be trained to provide follow up services that children placed in alternative are well taken care off.

The Guidelines exist for determining obligations for formal care settings and these are available in the Child Rights Law and the Edo State Children Protection Policy. Although informal care is recognized in the Child Rights Law, it is however not adequately addressed as no provisions is made to create a mechanism where informal care providers can be identified and monitored. There exist 
no robust data on the extent of care given to children and a lot of incidences of child abuse emanate from this area. It is noteworthy to state that in formal care, provisions are made to open a register where the child's detail is entered and follow-up via visitations to these homes are provided for in the Child Rights Law.

The Child Rights Law provides that all agencies, facilities and child related institutions must be duly registered by the Edo State Government and the State Government also has a responsibility of monitoring ensuring accountability. Sanctions are provided for violations of laid down regulations for instance imposition of fine or imprisonment of one year or both is given to a person who contravenes section 194(4).

\section{Conclusion}

An examination of the Edo State Child Rights Law 2007 as well as the Child Protection Policy of Edo State has been carried out with respect to the position of alternative care. Research shows that institutionalised alternative care is provided for in both legislations without provision for informal care. It has also been observed that there has been a high rate of violence on children especially under the informal care where children are given to relations and strangers without any proper mechanism put in place to monitor their well-being. This is considered to be an important aspect when compared with the UN Guidelines for Alternative Care for Children.

It is also observed that the Child Rights Law was enacted in 2007 while the UN guidelines came into effect in 2009. There is therefore the need to align provisions of the Child Rights Law with the UN guidelines. This then means that for an effective and efficient implementation of the extant laws, there are still areas that require immediate attention particularly with respect to the informal care area and it is recommended as follows:

That a proper mechanism be put in place to ensure effective monitoring as this will reduce greatly the incidences of child abuse in alternative care homes. For instance, the creation of registers where children and persons involved in informal alternative care are documented for effective monitoring.

There is also the issue of budgetary allocation for vulnerable families who on account of poverty give their children away or abandon them. It is suggested that Government should take the issue of such families seriously as it is often said the family is the bedrock of society and go all out to support poor households by creating an enabling environment in terms of employment opportunities, giving allowances to families who are poor and create a support system to enable parents take care of their children.

An agency is created whose main focus would be able to generate funds for the sole purpose of providing the necessary support with the aim of keeping families together with particular focus on children.

That a data bank for children be created to aid family tracing and reunifica- 
tion as this is really important so that when a child is released from an alternative care home, it can be easy for the child to be reunited with his/her family.

There is the urgent need to further sensitize the rural populace on the ills of giving out children for purposes of making their lives outside the home better. It is suggested that no matter the situation in the home, a child is entitled to grow up in his home as his rights will not be violated at will and his wish must be respected at all times.

Social workers are employed within local communities that would bridge the gap in terms of educating the populace and informing the relevant Ministry/ agencies on the need to reach out to families who require support.

That the provisions of the Child Rights Law 2007 and the Children Protection Policy 2015 be amended taking into considerations the UN Guidelines for the Alternative Care for Children and be adopted wholly as it will reduce the incidence of children leaving their families.

\section{Conflicts of Interest}

The authors declare no conflicts of interest regarding the publication of this paper.

\section{References}

Constitution of the Federal Republic of Nigeria (Constitution FRN) (1999). As Amended, Hereinafter Referred to as the Constitution, CAPC38, LFN2004.

Criminal Code Law, Edo State (1976). Sections 214-233A.

Edo State Child Protection Policy (2015). Sections 1, 3, 7-11, Section 2, Sub Section 4, 5, 7, Section 47 Sub Section 1, 2, 3, Sections 50 and 51, Sections 76(2),77(1-3).

Edo State Child Rights Law (2007). Section 1, 4, 5, 8, 54, 80, 81, Part XVIII, Section 192-193, Part XIII.

Edo State Government (2020). Information Got from the Capacity Building and Stakeholders Engagement on Alternative Child Care in Edo State held by Edo State Government in Collaboration with SOS Children's Villages Nigeria on 14-16 December 2020.

Edo State of Nigeria Gazette, Child Rights Law, ESCRL (2007). Hereinafter Referred to as CRL.

Federal Government of Nigeria (2020). http://www.ohchr.org

Independent Television (ITV), Radio (2020). Edo State Government Orders Arrest of Woman over Alleged Child Abuse.

http://www.web.facebook.com/itvradiong/videos/edo-state-govt-orders-arrest-of-wom an-over-alleged-1\& rdr

Ministry of Women Affairs and Social Development, Child Protection Policy, Edo State, (2015). p.3, 6, Hereinafter Referred to as Ministry of Social Development and Gender Issues.

Nnama-Okechukwu, C. U., \& Okoye, U. O. (2019). Rethinking Institutional Care Using Family-Based Alternative Child Care System for Orphans and Vulnerable Children in Orphans and Vulnerable Children in Nigeria. Journal of Social Work in Developing Societies, 1, 39-57.

https://www.bettercarenetworkorg/library/principles-of-good-care-practices/transform ing-institutional-care/rethinking-institutional-care-using-family-based-alternative-chil d-care-system 
Patience, U. (2020). Implementation of Alternative Care in Edo State. Presented at the Capacity Building \& Stakeholders Engagement on Alternative Child Care in Edo State, held 14-16 December at the Protea Hotel, Benin City, Edo State.

Save the Children Resource Center (2012). United Nations Guidelines for the Alternative Care for Children. Sections 12-14, 32, 69, 155, 156, 24, 25, 57, 68, 118-136.

https://resourcecentre.savethechildren.net/library/united-nations-guidelines-alternativ e-care-children

SOS Villages International (2018). How SOS Children's Villages Ensures the Best Care for Children and Young People. https://www.SOS CARE PROMISE EN Web.pdf

The Faith to Action Initiative (2014). Children, Orphanages and Families. http://www.resourcecentre.savethechildren.net/sites

The Guardian Newspaper (2018). Reports Incidence of Child Abuse and Sexual Abuse against Children Are on the Increase. http://www.m.guardian.ng

UNICEF (2020). Child Protection/UNICEFNIGERIA.

https://www.unicef.org $<$ Nigeria $>$ child 